\title{
Estimation of Walnut Production Function in Selected Province of Iran
}

\author{
Mahmoud Bakhshinejad
}

Department of Economics, Islamic Azad University, Shahrekord Branch, Shahrekord, Iran

Email: mahmoud46bakhshi@gmail.com

\author{
Doi:10.5901/mjss.2016.v7n3s3p312
}

\begin{abstract}
Production function is one that determines the output of a firm, an industry, or an entire economy for all combinations of inputs. This paper engaged Cob-Douglas production functions to test the factors effective on walnut (Juglans regia) production in Hamadan, Fars and Semnan provinces. The cross-sectional data collected from 383 Walnut Growers by questionnaire with interview schedule. The variables of this study were Zulonfloo poison, labor, machinery, Iron fertilization, water and acreage. The Cob-Douglas production function selected as the most appropriate model to analyze the walnut production function. Econometric analysis results revealed that walnut growers have used the factors of production in the second area of production. The Findings also showed the elasticity of factors production such as Zulonfloo poison, labor, machinery, Iron fertilization, water. The result showed that there is increase of Returns to scale in walnut orchards of Hamadan, Fars and Semnan provinces.
\end{abstract}

Keywords: Juglans regia, walnut orchards, Cob-Douglas production functions, Returns to scale, Elasticity of production.

\section{Introduction}

Walnuts are part of the tree nut family. This food family includes hazelnuts (filberts), pistachios, pecans, pine nuts... and walnuts. ((Anonymous (2008)), (Anonymous (2012))) Walnuts are a rich source of heart-healthy monounsaturated fats and an excellent source of those hard to find omega-3 fatty acids, walnut seeds are high density source of nutrients, particularly proteins and essential fatty acids. 100 grams of walnuts contain 15.2 gram protein, 65.2 gram fat, and 6.7 gram dietary fiber. The protein in walnuts provides many essential amino acids. Nutrients such as potassium, magnesium, phosphorus, iron, calcium, zinc, copper, vitamins B9, B6, E, A, and other substances have been found in walnuts (Koyuncu et al., 2004).

Absorbed of This product by domestic market is limited, so access the foreign markets is essential to enhance production. To achieve the global markets while other countries like America, China and Turkey have a long history of exporting the product, without improving quality, reducing cost of production and export infrastructure would not be possible. Walnut exports directly led to an increase in employment in manufacturing and ancillary industries and indirectly led to growth, rural development, poverty reduction and to achieve sustainable development. These days, the government has supported the export of agricultural products. Therefore, economic analysis of the walnut production like cost, technical, economic and allocate efficiency, productivity of factor production and problems of export in third province which has ranks seventh of walnut production in the country is essential.

Iran is ranked fourth in the world after USA, China and Turkey in walnut production (FAO, 2012). The production of walnuts was about 450000 tons per year in Iran and the harvested land area was 162,025 ha in 2012. Hamadan, Fars and Semnan provinces were the first walnut producer per hectare and provided one of the most desirable and high grade walnut of world (Anonymous, 2012). Therefore, determination of effective factors on the production of walnuts and estimation of walnut production function in these provinces and the estimate of walnut production could be particularly important in this regard. The objectives of this paper are:

1. To determine the effective factors of production of walnut.

2. To consider the different region of walnut production function for different inputs.

Kalirajan and Flinn (1983) estimated technical efficiency of production function in Malaysia. Stochastic frontier production function was used while the parameters of this model estimated maximum likelihood. The result showed that the average of technical efficiency was 75 percent. Mirotchie and Taylor (1993) examined the allocation of resources in cereal production in Ethiopia using Translog production function. The finding concluded that using of fewer workers, new modern machinery and inputs can be more desirable. The result also has been reported Low elasticity of substitution between labor and new inputs. Cumbacaro (1994) examined the efficiency farmers using random sampling in India. Tran 
slog production function was estimated using maximum likelihood. The results of this study showed that the mean technical efficiency is 46/75 percent. Brays and Robert (1994) have investigated the efficiency of rural farm in East Paraguay. Stochastic frontier production function has been used to determine efficiency of cotton and Sava. Their results showed that with current technology, there is a possibility of increasing profits. They stated the improvement of efficiency as a solution rather than increasing the acreage. Jafarzadeh (1995) estimated wheat production function using annual time series data during 1980 to 1994 in Khorasan. The relevant data of this article was collected through questioner. The result showed that the best consumption of fertilizer were $235 \mathrm{~kg}$ in watery cultivation and $335 \mathrm{~kg}$ in rainy cultivation. The result also showed that rain has positive effects on productivity of wheat production. Karianpour (1996) has evaluated Tarom rice production function and have considered the effective factors on it in Babolsar using cross-sectional data. The variables were acreage, seeds, labor, fertilizer, poison, water, education and Planting time. Quadratic production function using weight linear square (WLS) were estimated. The results showed that partial elasticity of acreage, labor and seeds were 10, 34, and 4 percent respectively. Rostamiyan (2001) analyzed economical production of Kolza in Mazandaran. The data was collected through questionnaire. Cob-Douglas and transcendental production functions were estimated while Cob-Douglas was selected as the best model. The results showed that increasing of Kolza production up to increasing of acreage and other variables such as poison and fertilizer have effective significant on production of Kolza. Safavi (2005) estimated kiwi production function in mazandaran. Data of this paper was collected through questionnaire using systematic sampling method. Quadratic production function was selected as the best model to analyze the data. The result showed that the fertilizer, labor and acreage were used less than Optimal. Binam and et al (2004) determined the effective factors on technical efficiency of farmers in Cameroon forests and agricultural systems, including groundnut, maize and groundnut - maize using stochastic frontier Cobb - Douglas production function. The variables were acreage, labor, production costs, seeds and tools of production. The total observations of these systems were 450 farmers. The results showed that the average of technical efficiency of the systems were 77,73 and 75 percent respectively. Oslo the result indicated that education, distance to roads, soil quality and join to agricultural communities and cash were had been affected on technical efficiency of farmers. Alvarez and Arias (2004) studied the relationship between technical efficiency and size of farm in the north of Spain during 1993 to 1998. In this paper production function was used which technical efficiency was used as one of their variables. The finding revealed that the influence of technical efficiency on size of farm depend on fixed inputs, inputs prices and price of variables. The results also indicated that there is positive relationship between farm size and technical efficiency. Noroozi (2011) have considered the optimal Production function and technical efficiency of rice in Kohgiloyeh VA Boyer-Ahmad province. Data required of this study was cross-sectional which was collected through questionnaire and interview with farmers. Cob-Douglas and transcendental production functions were estimated while Cob-Douglas was selected as the best model. The result showed that the technical efficiency of farmers had been 67.01 percent.

\section{Research Methods}

The data used in this study are cross-sectional data collected at 2012 (Table 1, Table 2). In addition to the data obtained by surveys, previous studies of related organizations such as Food and Agricultural Organization (FAO) and Ministry of Jihad-e-Agriculture of Iran (MAJ) were also utilized during this study. The size of sample of stratifications was determined by Neyman technique. (Zangeneh et al., 2010; Yamane, 1967) The size of 383 orchards was considered as adequate sample size. To achieve the research objectives, the data required for this study were collected through questionnaire by the method of interview. The kind of question in the questioner is open. To ensure the validity of the questionnaire, the experts in this field will be used. To check the validity of the questionnaire, Cornbrash's alpha test was used. In order to analyze the data and to estimate the models EVEIWS software package was used. After collecting the required data to achieve the research objectives, Cob-Douglas and transcendental production functions were estimated. 
Table 1: production costs of walnut in one hectare (Before productivity)

\begin{tabular}{|c|c|c|c|c|c|c|c|c|c|}
\hline \multirow[b]{2}{*}{ Rov } & \multirow{2}{*}{\multicolumn{2}{|c|}{ Type of cost }} & \multirow{3}{*}{\begin{tabular}{|l} 
Unit \\
$\mathrm{kg}$
\end{tabular}} & \multicolumn{3}{|c|}{ Costs in each turn } & \multirow{2}{*}{$\begin{array}{c}\text { Interval } \\
\text { between two } \\
\text { turns* }\end{array}$} & \multirow[b]{2}{*}{$\begin{array}{c}\text { Cost for one } \\
\text { year(\$) }\end{array}$} & \multirow[b]{2}{*}{$\begin{array}{c}\text { Cost for whole } \\
\text { period(\$) }\end{array}$} \\
\hline & & & & The amount & Unit & $\begin{array}{c}\text { Cost of } \\
\text { each turn }\end{array}$ & & & \\
\hline \multirow[t]{4}{*}{1} & \multirow[t]{4}{*}{$\begin{array}{l}\text { Chemical } \\
\text { fertilizer }\end{array}$} & Phosphate & & 132 & 0.028 & 3.7 & $\begin{array}{c}1.1 \\
1 \\
1 \\
1 \\
1\end{array}$ & 3.3 & 43.69 \\
\hline & & Urea & $\mathrm{kg}$ & 68 & 0.026 & 1.77 & 1.1 & 1.57 & 13.24 \\
\hline & & \begin{tabular}{|l|} 
Nitrate \\
\end{tabular} & $\mathrm{kg}$ & 33 & 0.016 & 0.53 & 1.1 & 0.47 & 6.2 \\
\hline & & \begin{tabular}{|l|} 
Other \\
\end{tabular} & $\mathrm{kg}$ & 65 & 0.021 & 1.365 & 1.1 & 1.22 & 16 \\
\hline 2 & Animal manure & & $\mathrm{kg}$ & 8397 & 0.003 & 25 & 1.8 & 13.75 & 182 \\
\hline \multirow{9}{*}{3} & \multirow{9}{*}{$\begin{array}{l}\text { Labor Plowing } \\
\text { and leveling }\end{array}$} & Plowing and leveling & $P / D^{*}$ & 5 & 15 & 75 & 0 & 75 & 75 \\
\hline & & $\begin{array}{l}\text { Crete Category and } \\
\text { canalization }\end{array}$ & $\mathrm{P} / \mathrm{D}$ & 5 & 15 & 75 & 0 & 75 & 75 \\
\hline & & $\begin{array}{l}\text { Shipping cost of } \\
\text { seedling and others }\end{array}$ & $P / D$ & 8 & 15 & 120 & 0 & 120 & 120 \\
\hline & & Pruning & $\mathrm{P} / \mathrm{D}$ & 2.7 & 15 & 40.5 & 1.04 & 42 & 556 \\
\hline & & $\begin{array}{l}\text { Using fertilizer and } \\
\text { spraying }\end{array}$ & $P / D$ & 4.3 & 15 & 64.5 & 1 & 64.5 & 838.5 \\
\hline & & Using shovel & P/D & 7 & 15 & 105 & 1.2 & 126 & 1668 \\
\hline & & Weeding & $\mathrm{P} / \mathrm{D}$ & 2.4 & 15 & 36 & 1 & 36 & 468 \\
\hline & & \begin{tabular}{|l|l|} 
Irrigation \\
\end{tabular} & $P / D$ & 0.8 & 15 & 12 & 1 & 12 & 159 \\
\hline & & \begin{tabular}{|l|l|} 
others \\
\end{tabular} & $\mathrm{P} / \mathrm{D}$ & 1.4 & 15 & 21 & 1 & 21 & 278 \\
\hline \multirow[b]{2}{*}{4} & \multirow[b]{2}{*}{ machine } & Plowing and leveling & No & - & - & 90 & - & 90 & 90 \\
\hline & & $\begin{array}{l}\begin{array}{l}\text { Crete Category and } \\
\text { canalization }\end{array} \\
\end{array}$ & No & - & - & 8.9 & - & 8.9 & 8.9 \\
\hline
\end{tabular}

*One person in a day

Source: research findings

Table 2: production costs of walnut in one hectare (Before productivity) [Continue]

\begin{tabular}{|c|c|c|c|c|c|c|c|c|c|}
\hline \multirow[b]{2}{*}{ Row } & \multirow{2}{*}{\multicolumn{2}{|c|}{ Type of cost }} & \multirow[b]{2}{*}{ Unit } & \multicolumn{3}{|c|}{ Costs in each turn } & \multirow[b]{2}{*}{$\begin{array}{l}\text { Interval between } \\
\text { two turns }{ }^{\star}\end{array}$} & \multirow[b]{2}{*}{$\begin{array}{c}\text { Cost for one } \\
\text { year(\$) }\end{array}$} & \multirow[b]{2}{*}{$\begin{array}{l}\text { Cost for whole } \\
\operatorname{period}(\$)\end{array}$} \\
\hline & & & & $\begin{array}{l}\text { The amount in } \\
\text { each turn }\end{array}$ & $\begin{array}{c}\text { Unit } \\
\text { price(\$) }\end{array}$ & $\begin{array}{l}\text { Cost of } \\
\text { each turn } \\
\text { (\$) }\end{array}$ & & & \\
\hline \multirow{5}{*}{4} & \multirow{5}{*}{ machine } & \begin{tabular}{|l|} 
Shipping cost of \\
seedling and others
\end{tabular} & - & - & - & 17.8 & - & 17.8 & 17.8 \\
\hline & & $\begin{array}{l}\text { Using fertilizer and } \\
\text { spraying }\end{array}$ & - & - & - & 1.3 & - & 1.3 & 17.25 \\
\hline & & Water engine & percent & 62 & & 13.45 & 13 & 174.85 & 2315 \\
\hline & & $\begin{array}{l}\text { Shipping fertilizer } \\
\text { and others }\end{array}$ & & & & 33.95 & 1 & 33.95 & 441 \\
\hline & & Other costs & & & & 16 & 1 & 16 & 209 \\
\hline 5 & Tools and & struments & & & & 17.6 & 1 & 17.6 & 232 \\
\hline \multirow{2}{*}{6} & \multirow{2}{*}{$\begin{array}{l}\text { Cost of } \\
\text { seedling }\end{array}$} & Initial seedling & Tree & 97 & 0.45 & 43.65 & & 43.65 & 43.65 \\
\hline & & Cultivated seedling & Tree & 14 & 0.6 & 8.4 & & 8.4 & 8.4 \\
\hline 7 & Land & & $\mathrm{Ha}$ & & & 664 & 1 & 664 & 8792 \\
\hline 8 & Water & & $\mathrm{M}^{3}$ & 122 & 0.04 & 504 & 13 & 70 & 929 \\
\hline \multicolumn{3}{|c|}{ Sum of production costs } & & & & & & 1738.26 & 13716.81 \\
\hline
\end{tabular}

${ }^{*}$ One person in a day

Source: research findings 
Douglas and transcendental production functions are as follows respectively:

$$
\begin{aligned}
& L N Y_{i}=B_{i}+B_{2} L N X_{1}+B_{3} L N X_{2}+\ldots \ldots \ldots \ldots .+B_{7} L N X_{6}+U_{i} \\
& L N Y_{i}=B_{i}+B_{2} L N X_{1}+B_{3} L N X_{2}+\ldots .+B_{7} L N X_{6}+B_{8} X_{1}+\cdots+B_{13} X_{6}+U_{i}
\end{aligned}
$$

Where $Y i$ is walnut production (in kg per), $X 1$ is Zolonfelo (in liter), $X 2$ is labor (in day), $X 3$ is machinery (in hour), $X 4$ is iron fertilizer (in $\mathrm{kg}$ ), $X 5$ is water (in hour), $X 6$ is acreage (in hectare), $B 1$ to $B 13$ are estimated parameters and $\mathrm{Ui}^{\text {is }}$ error term.

General F-test was used to select the best model between the estimated production functions as follow:

$$
F=\frac{R_{U R-}^{2} R_{R}^{2} / M}{1-R_{U R}^{2} /(N-K)}
$$

Where is determination coefficient of the unconstrained model (larger), is determination coefficient of the constrained model (smaller), $M$ is number of linear constraints, $N$ is observations and $K$ is parameters in the larger model. If the calculated $F$ exceeds from the critical value (Table $F$ and the degrees of freedom), we reject the null hypothesis, otherwise accept the unconstrained model.

\section{Analysis Result}

\subsection{Selection of the suitable model:}

Different production functions were estimated to analyze the walnut production in Hamadan, Fars and Semnan provinces which Cob-Douglas and transcendental production functions were selected between them. Other functions have been rejected because was very low, insignificant variables and Non-compliance with the methodology. For comparison CobDouglas and transcendental production functions and to choice the more appropriate Model, $F$ test was used as follows:

$$
\mathrm{F}=\frac{(0.7204-0.69820) / 6}{(1-0.7204) / 87}=
$$

Calculated $F(1.536)$ is less than critical $F\left(F_{0.05}(6,87)=2.25\right)$ at $5 \%$ level of significance, therefore Cob-Douglas production function is preferred.

\subsection{Estimation of Cob-Douglas production function:}

The cross-sectional data was used to estimate the Cob-Douglas production function. The estimation result of CobDouglas production function shows in Table 3.

Table 3: cob-Douglas production function

\begin{tabular}{|c|c|c|c|}
\hline Variables & coefficient & t-statistics & probe \\
\hline$C$ & 5.465 & 14.255 & 0 \\
\hline$L N_{X 1}$ & 0.526 & 16.675 & 0 \\
\hline$L N_{X 2}$ & 0.108 & 2.589 & 0.0452 \\
\hline$L N_{X 3}$ & 0.134 & 2.124 & 0.0604 \\
\hline$L N_{X 4}$ & 0.175 & 2.487 & 0.0103 \\
\hline$L N_{X 5}$ & 0.189 & 0.304 & 0.0114 \\
\hline$L N_{X 6}$ & 0.076 & 2.681 & 0.0279 \\
\hline$R^{2}=0.91$ & \multicolumn{3}{|c|}{ AKIC $=-0.050$} \\
$F=47.305$ & SC $=0.163$ \\
$D-W=2.103$ & SEE $=0.337$ \\
$N=300$ & \multicolumn{3}{|c}{} \\
\hline
\end{tabular}

Source: research findings

Now the econometric problems of regression like autocorrelation, multi co linearity, and heteroscedasticity and specification error of the model are considered. Auxiliary regression test was used for detection of multi co linearity in the model which it indicated that calculated $\mathrm{F}$ for all variables were significant at $1 \%$ level and it was less than critical $\mathrm{F}$ ( $\mathrm{so}$ there is no multi co linearity in the model. Heteroscedasticity is a problem in cross-sectional data. Arch and White test were used to detect hetroscedasticity which they confirmed that there is no heteroscedasticity in the model. For detection 
the existence of autocorrelation in the model, Durbin-Watson and LM test were used. DW, du and $\mathrm{dl}$ are 2.103, 1.726 and 1.628 respectively, $2<2.103<2.264$ so there is no autocorrelation in the model at $5 \%$ level of significance. RESET Ramzi test was used for specification the mode. The calculated $F$ equal 0.216 that rejected existence of error specification in the model. Determination coefficient of this model is 0.88 which shows 88 percent of Changes in the dependent variable has been explained by explanatory variables. The $\mathrm{F}$ of overall the regression is significant at $1 \%$ level of significance that indicated overall goodness of fit.

\subsection{Estimation of Transcendental production function:}

The estimation result of transcendental production function shows in Table 4.

Table 4: transcendental production function

\begin{tabular}{|c|c|c|c|}
\hline Variables & coefficient & t-statistics & Probe \\
\hline C & 5.461 & 2.425 & 0.042 \\
\hline$L N_{X 1}$ & 0.432 & 1.356 & 0.216 \\
\hline$L N_{X 2}$ & 0.362 & 2.634 & 0.014 \\
\hline$L N_{X 3}$ & 0.012 & 1.724 & 0.214 \\
\hline$L N_{X 4}$ & 0.021 & 0.103 & 0.768 \\
\hline$L N_{X 5}$ & 0.354 & 1.104 & 0.024 \\
\hline$L N_{X 6}$ & 0.213 & 1.542 & 0.134 \\
\hline$X_{1}$ & 0.134 & 1.864 & 0.164 \\
\hline$X_{2}$ & -0.134 & -2.324 & 0.721 \\
\hline$X_{3}$ & -0.321 & -0.804 & 0.621 \\
\hline$X_{4}$ & 0.124 & 0.542 & 0.891 \\
\hline$X_{5}$ & 0.013 & 0.346 & 0.901 \\
\hline$X_{6}$ & 0.214 & -0.846 & 0.624 \\
\hline$R^{2}=0.815$ & \multicolumn{3}{|c|}{$\mathrm{AKIC}=0.0345$} \\
$\mathrm{~F}=29.98$ & $\mathrm{SC}=0.423$ & \\
$\mathrm{D}-\mathrm{W}=2.521$ & $\mathrm{SEE}=0.421$ \\
$\mathrm{~N}=300$ & \multicolumn{3}{|l}{} \\
\hline
\end{tabular}

Source: research findings

Now the econometric problems of regression like autocorrelation, multicolinearity, and heteroscedasticity and specification error of the model are considered. Auxiliary regression test was used for detection of multicolinearity in the model which it indicated that calculated $\mathrm{F}$ for all variables were significant at $1 \%$ level and it was less than critical $\mathrm{F}$ ( so there is no multicolinearity in the model. Heteroscedasticity is a problem in cross-sectional data. Arch and White test were used to detect heteroscedasticity which they confirmed that there is no heteroscedasticity in the model. For detection the existence of autocorrelation in the model, Durbin-Watson and LM test were used. DW, du and dl are 2.521, 1.784 and 1.34 respectively, $2<2.521<2.61$ so there is no autocorrelation in the model at $5 \%$ level of significance. RESET Ramzi test was used for specification the mode. The calculated $F$ equal 1.458 that rejected existence of error specification in the model. The result of histogram normality showed that $J B$ is 1.54 which accepted normality of error term. Determination coefficient of the model is 0.87 which shows 87 percent of Changes in the dependent variable has been explained by explanatory variables. The $F$ of overall the regression is significant at $1 \%$ level of significance that indicated overall goodness of fit.

\subsection{Elasticity of production:}

After selection Cob-Douglas production function as the suitable function, is calculated Elasticity of production as follows:

$$
E_{p}=\frac{d L N y}{d L N x}
$$

The variables of this function were used as logarithm form, thus the coefficient of each variables are elasticity of its variable. The equation of this function is as follow:

$$
\mathrm{LNY}=5.345+0.628 L N_{X 1}+0.234 L N_{X 2}+0.046 L N_{X 3}+0.173 L N_{X 4}+0.145 L N_{X 5}+0.034 L N_{X 6}+\mathrm{Ui}
$$


According to the above equation, elasticity's of production shows in Table 5.

Table 5: inputs elasticity of walnut production

\begin{tabular}{|l|c|c|}
\hline Input & $X_{1}$ & Coefficient \\
\hline Zulonfloo position & $X_{2}$ & 0.628 \\
\hline Iabor & $X_{3}$ & 0.234 \\
\hline machinery & $X_{4}$ & 0.046 \\
\hline Iron fertilization & $X_{5}$ & 0.173 \\
\hline water & $X_{6}$ & 0.145 \\
\hline acreage & 0.034 \\
\hline
\end{tabular}

Source: research findings

According to Table 5, all coefficients are between 0 and 1 means Walnut growers have used the factors of production in the second area of production. The elasticity of factors production such as Zulonfloo poison, labor, machinery, Iron fertilization, water and acreage were $0.628,0.234,0.046,0.173,0.145$ and 0.034 respectively. Returns to scale:

Returns to scale are calculated from the whole elasticity in Cobb - Douglas production function.

$E=0.628+0.234+0.046+0.173+0.173+0.145=1.226$

The result of Wald test showed that there is increase of Returns to scale in walnut orchards of Hamadan, Fars and Semnan provinces. Therefore Returns to scale is 1.226 means Increase of one percent of all production factors simultaneously causes 1.226 present increases in product. The Cob-Douglas and transcendental production functions were estimated. But Cob-Douglas production function selected as the most appropriate model to analyze the walnut production function. The result of this study showed that Walnut growers have used the factors of production in the second area of production. The Findings also showed that the elasticity of factors production such as Zulonfloo poison, labor, machinery, Iron fertilization, water and acreage were $0.810,0.169,0.097,0.212,0.158$ and 0.093 respectively. Finally, the result of Wald test showed that there is an increase of Returns to scale (IRS) in walnut orchards of Hamadan, Fars and Semnan provinces.

Population growth, change of consumption habits, increase of daily consumption and its diversity has impact on increase of agricultural production. Therefore quantitative analysis of production through amount of optimum factors production in agriculture is major agricultural policies which it can increase production by ideal consumption of accessible sources.

\section{Reference}

Anonymous (2008). Food and Agriculture Organization (FAO). www.fao.org.

Anonymous (2012). Annual Agricultural Statistics. Ministry of Jihad-e-Agriculture of Iran, www.maj.ir. Accessed September 2, 2009.

Anonymous (2010). Wanak's Web, The Energy Stored in Food, Sprague High School, www.spraguehs.com. Accessed September 2, 2009.

Banaeian, N., Omid, M., Ahmadi, H. (2010): Energy and economic analysis of greenhouse strawberry production in Tehran province of Iran. Energy Conversion and Management, 52 (2): 1020-1025.

Daly, H. (1997): Forum on Georgescu-Roegen versus Solow/Stieglitz. Ecological Economics 22 (3): 261-306.

Canakci, A., Akinci, I. (2006): Energy use pattern analyses of greenhouse vegetable production. Energy, 31:1243-1256.

Canakci, M., Topakci, M., Akinci, I., Ozmerzi, A. (2005): Energy use pattern of some field crops and vegetable production: case study for Antalya region, Turkey. Energy Conversion and Management, 46:655-666.

Cobb C.W.P., Douglas H. (1928): A theory of production. American Economic Review 18(1):139-165. Supplement, Papers and Proceedings of the Fortieth Annual Meeting of the American Economic Association.

Cohen, A.J., Harcourt G.C. (2003): Retrospectives: Whatever Happened to the Cambridge Capital Theory Controversies? Journal of Economic Perspectives, 17(1):199-214.

De D., Singh R.S. Chandra H. (2001): Technological impact on energy consumption in rainfed soybean cultivation in Madhya Pradesh. Applied Energy, 70:193-213.

Demircan V., Ekinci K., Keener Hm., Akbolat D., Ekinci C. (2006): Energy and economic analysis of sweet cherry production in Turkey: a case study from Isparta province. Energy Conversion and Management, 47:1761-1769.

Erdal, G., Esengun, K., Erdal, H., Gunduz O. (2007): Energy use and economical analysis of sugar beet production in Tokat province of Turkey. Energy, 32:35-41.

Esengun, K., Erdal G., Gunduz, O., Erdal H. (2007): An economic analysis and energy use in stake-tomato production in Tokat province 
of Turkey. Renewable Energy, 32: 1873-1881.

Faidley, LW. (1992). Energy and agriculture. In: Fluck RC, editor. Energy in farm production. Elsevier Publication, Amsterdam.

Gezer, I., Acaroglu M., Haciseferogullari H. (2003): Use of energy and labor in apricot in Turkey. Biomass \& Bioenergy, 24(3): 215-219.

Hatirli, S.A., Ozkan B., Fert C. (2006): Energy inputs and crop yield relationship in greenhouse tomato production. Renewable Energy, 31:427-38.

Koyuncu, M.A., Ekinci and K., Sarvan E. (2004): Cracking characteristics of walnut. Biosystems

Engineering, 87(3): 305-311.

Mobtaker, Hg, Keyhani, A., Mohammadi, A. Rafiee S. Akram A. (2010): Sensitivity analysis of energy inputs for barley production in Hamedan Province of Iran. Agriculture Ecosystem and Environment, 137 (3-4): 367-372.

Mohammadi, A., Omid M. (2010): Economical analysis and relation between inputs and yield of greenhouse cucumber production in Iran. Applied Energy, 87:191-196.

Mohammadi, A., Rafiee, S., Mohtasebi, Ss., Rafiee, SH. (2010): Energy inputs-yield relationship and cost analysis of kiwifruit production in Iran. Renewable Energy 35:1071-1075

Ozkan B., Akcaoz, H., Karadeniz F. (2004): Energy requirement and economic analysis of citrus production in Turkey. Energy Conversion and Management, 45:1821-1830.

Ozkan, B., Kurklu, A., Akcaoz, H. (2004): An input-output energy analysis in greenhouse vegetable production: a case study for Antalya region of Turkey. Biomass \&Bioenergy, 26(1): 89-95.

Rafiee, Sh., Mousavi, Avval Sh., Mohammadi, A. (2010): Modeling and sensitivity analysis of energy inputs for apple production in Iran. Energy, 35 (8): 3301-3306.Science.

Singh, G., Singh, S., Singh, J. (2004). Optimization of energy inputs for wheat crop in Punjab. Energy Conversion and Management, 45:453-465.

Singh, S., Mittal, Jp. (1992). Energy in Production Agriculture. Mittal Publication, New Delhi.

Stewart, J. (2008). Calculus: Early Transcendental. Thomson Brooks/Cole, 6th Edition, Pages 857 and 887.

Stout BA. (1990). Handbook of energy for world agriculture. Elsevier Publication, London.

Strapatsa, Av., Nanos, Gd., Tsatsarelis, Ca. (2006): Energy flow for integrated apple production in Greece. Agriculture Ecosystem and Environment, 116:176-180.

Tabatabaeefar, A., Emamzadeh, H., Varnamkhasti, Mg. Rahimizadeh, R., Karimi M. (2009). Comparison of energy of tillage systems in wheat production. Energy, 34:41-45.

Wiens, Mj. Entz Mh. Wilson C., Ominski, KH. (2008): Energy requirements for transportation and surface application of liquid pig manure in Manitoba, Canada.Agricultural Systems, and 98:74-81.

Yaldiz, O., Ozturk, Hh. Zeren, Ya. Bascetomcelik (1993): Energy usage in production of field crops in Turkey. In: 5th International congress on mechanization and energy use in agriculture; 11-14 October, Kusadasi, Turkey.

Yamane, T. (1967). Elementary sampling theory. Engle wood Cliffs, NJ, USA: Prentice-Hall Inc.

Yilmaz I., Akcaoz H., Ozkan B. (2005): An analysis of energy use and input costs for cotton production in Turkey. Renewable Energy, 30:145-155.

Zangeneh, M., Omid, M., Akram A. (2010): A comparative study on energy use and cost analysis of potato production under different farming technologies in Hamedan province of Iran. Energy, 35: 2927-2933.Received for 11, 2011 publication: November 30, 2010 Accepted for publication: October 